regional groupings (the Caribbean; the Pacific; and Africa, Indian Ocean, Mediterranean and South China Sea).

Members. As of Feb. 2018 AOSIS comprised 37 nation states (plus the New Zealand dependencies of the Cook Islands and Niue): Antigua and Barbuda, The Bahamas, Barbados, Belize, Cabo Verde, Comoros, Cuba, Dominica, Dominican Republic, Fiji, Federated States of Micronesia, Grenada, Guinea-Bissau, Guyana, Haiti, Jamaica, Kiribati, Maldives, Marshall Islands, Mauritius, Nauru, Palau, Papua New Guinea, St Kitts and Nevis, St Lucia, St Vincent and the Grenadines, Samoa, Singapore, Seychelles, São Tomé and Príncipe, Solomon Islands, Suriname, Timor-Leste, Tonga, Trinidad and Tobago, Tuvalu and Vanuatu. A further five non-sovereign territories have observer status.

Website: http://aosis.org

Chairperson: Ahmed Sareer (Maldives).

\section{Amnesty International (AI)}

Origin. Founded in 1961 by British lawyer Peter Benenson as a one-year campaign for the release of prisoners of conscience, Amnesty International has grown to become a worldwide organization, winning the Nobel Peace Prize in 1977.

Activities. AI is a worldwide movement of people campaigning for human rights. It acts independently and impartially to promote respect for internationally recognized human rights standards.

Historically, the focus of AI's campaigning has been: to free all prisoners of conscience (a term coined by Peter Benenson); to ensure a prompt and fair trial for all political prisoners; to abolish the death penalty, torture and other cruel, inhuman or degrading punishments; to end extrajudicial executions and 'disappearances'; to fight impunity by working to ensure perpetrators of such abuses are brought to justice. AI is independent of any government or political ideology, and neither supports nor opposes the views of the victim it seeks to protect.

AI has over $3 \mathrm{~m}$. members, subscribers and regular donors in more than 150 countries. Major policy decisions are taken by an International Council comprising representatives from all national sections. AI's national sections, members and supporters are primarily responsible for funding the movement. In 2015 Amnesty International raised $€ 278 \mathrm{~m}$. for human rights work.

Every year AI produces a global report detailing human rights violations in all regions of the world.

International Secretariat: 1 Easton St., London,

WC1X 0DW, UK.

Website: http://www.amnesty.org

Email: contactus@amnesty.org

Secretary-General: Salil Shetty (India).

\section{Further Reading}

Power, Jonathan, Like Water on Stone: The Story of Amnesty International. 2001

\section{Bank for International Settlements (BIS)}

Origin. Founded on 17 May 1930, the Bank for International Settlements is the world's oldest international financial organization.
Activities. The BIS fosters international monetary and financial co-operation and serves as a bank for central banks. It acts as a forum to promote discussion and policy analysis among central banks and within the international financial community, a centre for economic and monetary research and an agent or trustee in connection with international financial operations.

As its customers are central banks and international organizations, the BIS does not accept deposits from, or provide financial services to, private individuals or corporate entities.

The head office is in Basle, Switzerland, and there are representative offices in Hong Kong and Mexico City.

Representative Office for Asia and the Pacific: 78th Floor, Two International Finance Centre, 8 Finance St., Central,

Hong Kong SAR, People's Republic of China.

Representative Office for the Americas: Torre Chapultepec,

Rubén Dario 281, Col. Bosque de Chapultepec, 11580 México,

D. F., Mexico.

Headquarters: Centralbahnplatz 2, CH-4051 Basle, Switzerland.

Website: http://www.bis.org

Email: email@bis.org

Chairman of the Board of Directors: Jens Weidmann (Germany).

\section{Commonwealth}

The Commonwealth is a free association of sovereign independent states. It numbered 53 members in Feb. 2018. With a membership of over $2 \mathrm{bn}$. people, it represents around $30 \%$ of the world's population. There is no charter, treaty or constitution; the association is expressed in co-operation, consultation and mutual assistance for which the Commonwealth Secretariat is the central co-ordinating body.

Origin. The Commonwealth was first defined by the Imperial Conference of 1926 as a group of 'autonomous Communities within the British Empire, equal in status, in no way subordinate one to another in any aspect of their domestic or external affairs, though united by a common allegiance to the Crown, and freely associated as members of the British Commonwealth of Nations'. The basis of the association changed from one owing allegiance to a common Crown, and the modern Commonwealth was born in 1949 when the member countries accepted India's intention of becoming a republic at the same time as continuing her full membership of the Commonwealth of Nations and her acceptance of the King as the symbol of the free association of its independent member nations and as such the Head of the Commonwealth'. In Feb. 2018 the Commonwealth consisted of 32 republics and 21 monarchies, of which 16 are the Queen's realms. All acknowledge the Queen symbolically as Head of the Commonwealth. The Queen's legal title rests on the statute of 12 and 13 Will. III, c. 3, by which the succession to the Crown of Great Britain and Ireland was settled on the Princess Sophia of Hanover and the 'heirs of her body being Protestants'.

A number of territories, formerly under British jurisdiction or mandate, did not join the Commonwealth: Egypt, Iraq, Transjordan, Myanmar (then Burma), Palestine, Sudan, British Somaliland and Aden. Seven countries (Ireland in 1948, South Africa in 1961, Pakistan in 1972, Fiji in 1987, Zimbabwe in 2003, The Gambia in 2013 and the Maldives in 2016) have left the Commonwealth. Pakistan was readmitted to the Commonwealth in 1989, South Africa in 1994, Fiji in 1997 and The Gambia in 2018. Nigeria was fully suspended in 1995 for violation of human rights but was fully reinstated on 29 May 1999. Pakistan was suspended from the Commonwealth's councils following a coup in Oct. 1999 but was readmitted in May 2004. It was again suspended in Nov. 2007 after then President Musharraf declared 